\title{
Information reliability: criteria to identify misinformation in the digital environment
}

\author{
Leonardo Ripoll* \\ José Claudio Matos**
}

Artículo recibido:

6 de mayo de 2019

Artículo aceptado:

7 de noviembre de 2019

Artículo de revisión

\section{Abstract}

The article presents information reliability criteria to identify misinformation and its representations (fake news, post truth, alternative facts and deepfake) in the current scenario, characterized by the digital environment. It also contextualizes the concepts of critical reading and critical thinking, essential in the conceptual formulation of informational reliability. From there, the paper elaborates its criteria in order to verify the reliability of information disseminated in the web. For this purpose, it uses the criteria to evaluate information sources developed by Tomaél, Alcará and Silva

* Universidade Federal de Santa Catarina, Brasil

** Universidade do Estado de Santa Catarina, Brasil

leonardo_ripol|@hotmail.com doutortodd@gmail.com

INVESTIGACIÓN BIBLIOTECOLÓGICA, vol.34, núm. 84, julio/septiembre, 2020, México, ISSN: 2448-8321 pp. 79-101 
(2008), the critical analysis of arguments by Carraher (1983), and Floridi's $(2011,2010)$ concept of informativeness and also his informational concept map. The article concludes that these criteria help to combat misinformation, and stimulate critical reading and thinking processes in the individual, even though they are not a final solution for this purpose.

Keywords: Disinformation; Information Reliability; Fake News; Information Sources

Fiabilidad informativa: criterios para la identificación de desinformación en el entorno digital Leonardo Ripoll y José Claudio Matos

RESUMEN

El artículo presenta criterios de fiabilidad informativa para identificar la desinformación y sus representaciones (fake news, posverdad, hechos alternativos, deepfake) en el escenario actual caracterizado por el entorno digital. Contextualiza los conceptos de lectura crítica y pensamiento crítico, que son esenciales en la formulación conceptual de la fiabilidad informativa. A partir de ahí, elabora sus criterios para verificar la fiabilidad de las informaciones difundidas en la web. Utiliza para ello los criterios de evaluación de las fuentes de información desarrollados por Tomaél, Alcará y Silva (2008), el análisis crítico de argumentos de Carraher (1983), el concepto de informatividad y el mapa de conceptos informativos de Floridi (2010 y 2011). El artículo concluye que los criterios pueden auxiliar en acciones de combate a la desinformación y estimular procesos de lectura y pensamiento crítico en el individuo, pero que no sean una solución final dirigida a este objetivo.

Palabras clave: Desinformación; Fiabilidad Informativa; Fake News; Fuentes de Información 


\section{INTRODUCTION}

7 he increase of misinformation in the digital environment has required from persons a new form of behavior within the social dynamics that involve information. Such increase, as demonstrated by recent research (such as Vosoughi, Roy and Aral, 2018; Bennett and Livingston, 2018; Posetti, 2018; Vicario et al. 2016, and Silverman, 2015), brings economic and social effects, and requires a change in science and information professionals concerning the transmission of knowledge. Above all, it requires that actions to combat misinformation be planned and carried out.

The dissemination of misinformation in the form of fake news, post-truth, alternative facts and deepfakes suggests that what Lévy (2010) presented as the purpose of 'cyberspace' seems questionable: are we actually experiencing 'collective intelligence' processes? Or are we seeing its reverse effect through 'collective stupidity' (Moretzsohn, 2017)?

Olmo y Romero, in her article "Desinformación: concepto y perspectivas" (2019: 3), recognizes that: "Each individual has become a means of communication in itself that only shares what he wants and what he agrees with, more often than not stopping to think". It means that the interconnectivity made possible by technology brings a situation of crisis, because the waves of misinformation in the digital environment. The author calls attention for the fact that: "While it is difficult to quantify the influence of a disinformation campaign, what is evident is its corrosive power in the medium and long term" (Olmo y Romero, 2019: 4). In this sense, to identify and combat misinformation becomes a survival necessity in the contemporary cultural environment.

Marcos Recio, Sánchez Vigil and Olivera Zaldua (2017) argue that the increasing quantity of information from the 21st century does not mean an information improvement. As information is quickly spread on social networ$\mathrm{ks}$, what matters now is to find reliable information paths and sources, such as the fact-check initiatives.

Although educational measures, such as the Media and Information Literacy (MIL) (Dudziak, Ferreira and Ferrari, 2017) have already been present for some time in the academic discussions and in the pedagogical agenda of many schools and universities, other actions are also necessary to prepare the individual in the task of interpreting, reading and sharing information of this environment. The presentation of criteria to evaluate the reliability of information is intended to equip the individual quickly and practically with a minimum of care that should be taken with the information in the current context, starting from critical reading and thinking process. 
The methodology used in this study is qualitative. Its main result is the formulation of theory, in the form of fundamental concepts and criteria to operate with these concepts. The study started from bibliographic research on the themes of misinformation, critical thinking and informational reliability. The formulation of the main concepts and criteria to identify the misinformation was made through the analysis and critical interpretation of the productions identified by the bibliographic research. In this sense, this study results in the formulation of theory based on the discussion of the results of other researches, and the consideration of the phenomenon of misinformation, in its most general and broad sense, as it has been represented in the state of scientific and philosophical discussion.

It is important to explain that misinformation and disinformation have different meanings. As Floridi $(2011,2010)$ and Fallis (2015) claim, the difference between disinformation and misinformation lies in the awareness of the act: while in disinformation there is an intention to deceive, in misinformation the action is made by mistake. Thus the distinction is based upon the notion of purpose of the agent that communicates or transmits messages. However, as Fallis (2015) argues, it is more standard to use the term 'misinformation' when referring to the general meaning.

\section{THE CONCEPTS OF CRITICAL READING AND CRITICAL THINKING}

The criteria developed in this article, therefore, aim to introduce critical reading and thinking into the routine of the individual's mental processes that deal with information.

A brief analysis of some definitions found for the words 'criticism' and 'criteria' shows that the relationship between the two is very close because they demonstrate complementary purposes. 'Criteria', from the Greek kritrion, is related to the ability to distinguish the true from the false, and the authority to criticize (Cambridge English Dictionary, 2019a). Criticism, however, refers to the analysis of intellectual productions, the capacity to judge, the analysis of facts (Cambridge English Dictionary, 2019b). Establishing criteria is then closely related to critical activity. But, what would be the critical reading? Related to other concepts such as 'critical thinking', 'critical writing' and Media and Information Literacy, it is an important cognitive tool for dealing with misinformation.

The concept of 'critical reading' varies according to the area in which it is defined. In general, its origin seems to lay in philosophy, and its elaboration took place along with the very development of reason. Whether it is 
through the interpretation of reality (philosophy), the interpretation of texts (hermeneutics, exegesis) or the development of the scientific method, critical reading has always been present in the quest for knowledge. Thus, critical reading inevitably became the academic basis for learning, and it is common to find its definition in study support documents in some universities. For example, according to the University of Leicester (2009: 1), critical reading is understood as a study skill that involves:

- examine the evidence or arguments presented;

- check out any influences on the evidence or arguments;

- check out the limitations of study design or focus;

- examine the interpretations made; and

- decide to what extent you are prepared to accept the author's arguments, opinions, or conclusions.

It points out that a critical reading should seek the so-called 'evidences'. Although the evidence is different depending on the type of text (which may be scientific or a personal account, for example), they are usually attributed to the presentation of data external to the text and the rational construction of an argument (e.g., the context in which the information was collected, or the presentation of the methodology used). In addition to the evidence, the text will present arguments, and it is the role of the critical reader to question these arguments (e.g., why was this done so and why did the author choose this evidence?) Are the conclusions consistent with the premises? Are the comparisons made appropriately? Does the line of reasoning make sense?) (University of Leicester, 2009).

For Cleveland State University, critical reading involves reaching a level of depth of the text, possible only if the "reader applies certain processes, models, questions, and theories that result in enhanced clarity and comprehension" of the message received (Cleveland State University, 2017). Still according to the university, logical consistency is one of the important terms in the process of critical reading:

Critical reading involves using logical and rhetorical skills. Identifying the author's thesis is a good place to start, but to grasp how the author intends to support it is a difficult task. More often than not an author will make a claim (most commonly in the form of the thesis) and support it in the body of the text. The support for the author's claim is in the evidence provided to suggest that the author's intended argument is sound, or reasonably acceptable. What ties these two together is a series of logical links that convinces the reader of the coherence of 
the author's argument: this is the warrant. If the author's premise is not supportable, a critical reading will uncover the lapses in the text that show it to be unsound. (Cleveland State University, 2017)

According to these definitions, critical reading is commonly associated with procedures of scientific methodology (and scientific thinking in general) for the formation of the future researcher. But it is also widely used as a theoretical and philosophical problem in disciplines within the area of Human Sciences (such as Pedagogy) or in the area of Communication. In this way, it is easy to associate the critical reading with the concept of 'critical consciousness' proposed by the famous Brazilian educator, Paulo Freire. According to Freire (1988), critical consciousness is problematizing, dialogic, inquirer and investigative. It seeks to go beyond appearances, interprets problems in depth, perceives reality as changeable, and is open to revisions. It avoids prejudices and deformations in interpretations, practices the dialogue between the new and the old, and seeks security in argumentation, instead of controversy.

Behind critical reading there are cognitive processes responsible for their execution: such processes constitute critical thinking. In essence, critical thinking is related to the act of analysis that guides critical reading. For the professor and researcher in psychology, David William Carraher (1983: 127128), the critical analysis

is the process by which questions are clarified. We stress the word critic because whoever makes such an analysis requires that his ideas be examined and questioned. Doubts help us to ask questions. The critical thinker, in weighing the arguments of himself and others, raises many questions, including the following:

- What is being stated? Are there ideas implicit in the argument?

- What is used to support ideas?

- Does the evidence (if any) support ideas?

- Are there important facets of the problem addressed that were not considered? What do other perspectives suggest?

- Does the author well characterize the problem addressed? Or does your characterization distort the problem?

- What are the key issues involved? Does the author acknowledge the centrality of such issues? Are these questions, in fact, of value or conceptual?

- What information could help clarify the main issues?

- What ideas or concepts need to be explored to clarify the main issues?

For Carraher (1983), the ideas of an author are presented within a specific logic, that determines a position on a certain subject. A critical reader, according to Carraher (1983), knows not only to recognize the place of each 
argument within the same subject, but also to evaluate which is the most appropriate or better formulated. Still according to the author, critical thinking is also related to the notion of critical sense.

The philosopher and educator John Dewey, develops the notion of critical thinking under the term 'reflexive thought'. According to Dewey (1997: 21), reflexive thought unleashes "a logical sequence of stages of thought that results in a substantial conclusion to order a sequence of ideas".

In reading, it also corresponds to the reader's mental process in seeking indications of answers (or 'suggestions', in the terminology of the author) in the face of a situation of doubt and uncertainty provoked in the action of reading a text. For Dewey (1997), reflexive thinking fights 'prejudices' mentally acquired as 'thoughts' in an automated way by the individual in their social context. In Dewey's words (1997: 19):

Such "thoughts" develop unconsciously. They are harvested - we do not know how. From obscure sources and unperceived channels, they insinuate themselves in the spirit and unconsciously become a part of our mental garrison. They are responsible for tradition, education, imitation, which all depend in some way on authority, or attend to our own advantage, or coincide with some strong emotion of ours. [...] Even when it happens to be correct, its correction is accidental when it comes to the person who has them.

This passage presents some important points. First, it emphasizes the importance of critically thinking as a way of challenging values that are reproduced through communication without question. So, it is inevitable to refer to the idea of 'common sense'. Critical sense provides knowledge by reflection, and thereby corrects and organizes common sense. The expression "common sense" is understood here as a great body of knowledge and conduct that, in many cases, is organized by the mere 'transfer', by the simple automated acquisition of information.

This acquisition, well represented in the passage through the word 'imitation', brings the second important point: the dissemination of information from the point of view of the so-called 'memes'. The term, widely used today in the dissemination of humoristic information on social networks (and in constant sharing of territory with fake news), was originally coined in the 1970s by the scientist and writer, Richard Dawkins, in his work The selfish gene. According to Dawkins (2007), the 'meme' would be equivalent to the cultural counterpart of the gene and thus would be responsible for the reproduction, through generations and populations, of the various human artifacts produced under the most diverse manifestations that reach the cultural 
sphere: languages, gestures, dances, ideas, forms of behavior, among others. Memes circulate in culture and replicate themselves, but their dissemination always occurs through critical and rational reflection. Many memes are adopted, like prejudices or fashions, without going through conscious examination. Therefore, due to the memes, the human being can acquire thoughts that do not correspond to the exercise of the reflection itself.

The last point on the Dewey's passage corresponds to the use of the words 'emotion' and 'advantage'. Dewey seems to suggest that some thoughts are acquired in an automated way by being in accordance with some emotional appeal of the individual, or by the fact of producing some kind of advantage. The importance of this argumentation is precisely due to its direct relation with the concept of post-truth, which refers to situations in which appeals to beliefs and emotions overlap the facts (Oxford University Press, 2019).

Thus, if Dewey's reflexive thought hopes to be a way of set apart from the minds of individuals these other types of 'thoughts', the critical thinking proposed here is intended to be a way of countering the current scenario of post-truths, false news, alternative facts and misinformation as a whole. However, adapted in terms of the proposal of this article, the critical reading is defined as the capacity for reasonable analysis of the information that is read, in order to question its truth, origin, purpose and its correspondence with the facts. This analysis requires the use of reliability criteria, so that it can have a reference for judgment. It is rational insofar as it follows logical rules, and seeks the argumentative form in which a conclusion must be supported by justifications or evidences, only then to be admitted as valid.

Critical thinking, however, is conceptualized as the mental process that underlies critical reading, which seeks careful examination of information, aiming to make decisions and generate knowledge. This thinking, of course, is not only about reading texts, but about any relation between the persons and the objects from which one hopes to obtain new information or knowledge. Critical thinking is the general principle from which critical reading is a specific case.

The concepts brought here intend to enable the individual and society to choose correctly how, when and where to inform. But what is the correct form? In this case, it is understood as 'correct', the informational path that leads to knowledge, that is, that responds truthfully (as corresponding to reality) what the individual wants to know. How do you know if this or that answer is true? One way to ascribe truth to an idea, theory, or answer to any question is to determine to what extent the information contained therein is reliable. But, to one can determine reliable information, it is necessary to ascertain criteria that guarantee such a characteristic, which is its reliability. 


\section{THE INFORMATION RELIABILITY}

The conceptual development of the information reliability notion has been elaborated more extensively in Leite (2018), which used as basis the epistemological discourses of Floridi (2011) and Goldman (1993) on factual information, semantic information, reliabilism, justified belief and knowledge. This development was based on the absence of records in the literature defining the term, applied to the theme of misinformation in the digital environment.

It should be noted that epistemic notions of reliability are always related to the knowledge of something or to a belief that is being operated in some sense by the individual. This belief is usually associated with cognitive processes of a logical nature or perceptions transmitted by the senses. Goldman (1993), for example, proposes that one of the solutions to assessing the confidence in a justified belief is the creation of a list of intellectual virtues and vices. In this case, the virtues would be understood just as reliable cognitive processes. Thus, epistemic evaluators would judge whether a particular case resembles a virtue or a pre-established cognitive defect in the list.

Similar to what Goldman proposes, it is understood that the development of reliability criteria is what makes the very notion of reliability become more solid. Therefore, the development of such criteria is a way to create a consistent notion of information reliability and to evaluate information disseminated in the virtual environment.

The notion of reliability is also explored by Floridi (2011) in his discussion of what he calls 'semantic information' and his 'veridicality thesis'. Reliability is based, above all, on exercising criticalness in matters of knowledge and belief. If the critical exercise of reason is the principal way of attaining knowledge, it is also the method of discerning which paths lead to there. It is also worth noting the use of the word 'belief' in this discussion. According to a widely used meaning in epistemological discussions, belief is a content that relies on an individual's willingness to act toward him.

Charles Peirce, the founding philosopher of the school of pragmatism, in his article "The fixation of belief" states that: "Our beliefs guide our desires and shape our actions" (Peirce, 1980: 98). In a rigorous and technical sense, Peirce (1980: 98-99) comments on the belief that: "So it is with all belief according to its degree. The feeling of believing is a more or less sure indication of being established in our nature some habit that will determine our actions".

Believing, therefore, involves practically all human behavior in relation to knowledge and information. Believing in false things can lead to the failure of our behaviors, and can threaten our well-being and even our lives. So, the question of deciding what information someone will believe in, is of the most 
fundamental importance, especially in a cultural environment where true and false messages, information and misinformation are circulating together.

\section{INFORMATION RELIABILITY CRITERIA}

Informational reliability is defined as the process that evaluates, using pre-determined criteria, whether the content of certain information is true or reliable. It evaluates whether or not we are justified in maintaining belief about certain information, and to what degree this belief can be maintained.

These criteria, which will determine the level of reliability of the information, are presented in two dimensions:

- Technical dimension: involves aspects related to the format and context in which the information is presented;

- Semantic dimension: involves the semantic and logical contents of the information itself.

From these two dimensions, this investigation expects to establish a method for the analysis of information disseminated in the informal context of the web, applicable to the monitoring of information disseminated in the digital environment.

It is time to specify which type of information is the focus of the application of these criteria. Such information, first of all, is information that Floridi (2011) defines as "factual semantic". That is, the one that can be evaluated as true or false, according to Figure 1.

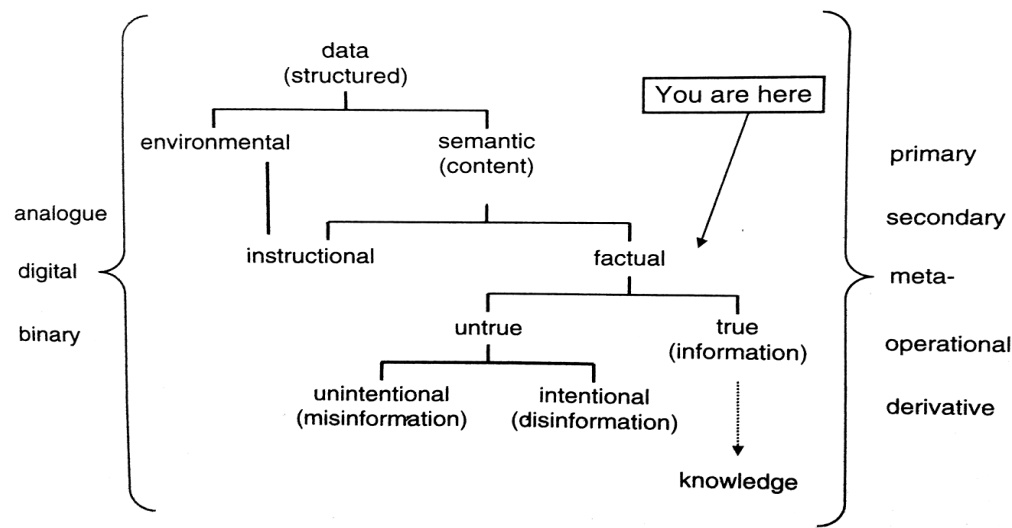

Figure 1. Map of information concepts Source: Floridi (2010: 49) 
In addition, the developed criteria are directed to the information that is:

- Non-environmental or biological: it is not information present in the natural environment or in living organisms (such as climate, fingerprints or DNA);

- Elaborated by the human being: and, thus, resulting from subjectivities;

- Language dependent: therefore, with syntactic and semantic content;

- Writing: presented in textual form and, therefore, dependent on readings and interpretations;

- Factual: May be judged true or false. It is not, therefore, an instructional information;

- Available on the web: present in the environment known as 'digital';

- Advance from news sites, portals and blogs: and therefore, it is current information, usually written in accessible and informal language. It does not cover publications in scientific journals. In this way, it is also characterized as being information commonly written without editorial screening;

- Used, not infrequently, for purposes other than inform: subject to distortions and manipulations in its content. It may thus appear under the various forms of disinformation.

\section{Technical dimension}

The technical dimension, as previously mentioned, analyzes issues related to the format and context of the information presentation. It is the dimension that deals with a practice already developed for a long time by Library and Information Science, within the field of research in information sources, stands out the works led by the Brazilian researcher Maria Inês Tomaél.

Initially, the technical analysis of the reliability of information conveyed by a text in the digital environment should be mainly concerned with the question of authorship and the source of the information in focus. The first step in understanding what kind of information this is - and what level of trust one can begin to apply - is to identify the source of the information.

Hjørland (2012) elaborated a catalog of some methods consolidated in the literature, for the evaluation of sources of information. The author explains that the context of the information abundance has increased the studies in the evaluation of sources of information. Tomaél, Alcará and Silva (2008) comment that the quality of information has been a challenge since the expansion of the web. They also mention the existence, at present, of an information overloading process. 
In his study, Hjørland (2012) identifies the relevance of at least four methods that have specific relation with the authorship of the information: author credentials, publisher reputation, journal impact factor, and sponsoring. The author considers that, even if these are valid evaluation measures, they are indirect in relation to the content itself, and should not be considered isolated. Other methods presented by Hjørland (2012) include evidence-based evaluation, which examines the evidence (research methods or sources used) that a particular text uses to articulate its considerations, and comparative studies, that evaluate the content of a text comparing it with other texts, wich are references on the treated topic.

However, the parameters developed by Tomaél, Alcará and Silva (2008) aim at the evaluation of the informational source, in a broader way. That is, in addition to evaluating the information itself, they also seek to evaluate aspects of usability, accessibility, navigation, organization, security and interoperability of the source. With regard to the present research, the indicators of 'intrinsic aspects' (content) and 'credibility' (authorship) seems effectively relevant for the development of reliability criteria.

As part of the 'intrinsic aspects', Tomaél, Alcará and Silva (2008) cite 'reliable and credible information', along with 'truth' (within the criteria of 'accuracy' of information), and information 'based on facts', along with 'impartiality' (within the criteria of 'objectivity'). In addition to these, they also cite 'ease of understanding (clarity)', 'consistency and relevance', 'update', 'integrity' and 'reach' as criteria.

The authors place the criteria related to the authorship and responsibility of the source within the 'credibility' indicator. For them, the authority criteria are used as a synonym for reliability, since the credibility of an author in a particular area, or the identification of a site as academic or governmental, determine the reliability of a source (Tomaél, Alcará and Silva, 2008).

In general, the Hjørland study (2012) presents a guide to the evaluation of academic and scientific information sources. Their surveys and critics end up being a discussion about the methods of evaluation and validation of the knowledge produced by the scientific research, including its metrics, pointing out possible limitations and failures of each method, and instigating skepticism in relation to the total confidence in the procedures conducted in each situation. Hjørland (2012) also argues that methods should not be ends in themselves, they are but a few steps in the larger process of learning how to read, understand, and criticize texts.

Tomaél, Alcará and Silva (2008), in turn, focus their study on the role of the information professional as mediator of information: he or she must perceive the information needs of his or her user and also act as a filter of 
information quality, always leading in mind that this filter must be made in relation to the demands of the user. Thus, ultimately, for the authors, what determines the quality of an information is how well it is adequate to satisfy the needs of the user. Although this may be a problematic definition from the epistemological point of view, Tomaél, Alcará and Silva (2008) proposed some criteria that can be detached from their context of formulation, to collaborate in the development of the technical dimension of reliability presented here. The authors mention that, due to constant changes in the web, the parameters should always be revised, re-adjusted and therefore serve as a method of reflection rather than a complete and ready evaluation tool.

The studies mentioned above form a theoretical basis for the technical analysis of reliability of an information. Thus, consider them, together with the theoretical basis about critical reading, and adapting to the information delimited by this research (described above), the criteria of the technical dimension are thus able to determine the information reliability. These criteria, presented in topics, are explained in forms of questioning, which should be done by the user as a way of exercising critical thinking.

It is important to emphasize that all questions are not necessarily expected to be answered at the time of analysis (although the more a criteria is properly answered, the more likely the content will be reliable). The questions are proposed to act as a guide to an important verification path that should be followed by the reader.

\section{Information reliability criteria (technical dimension)}

- Authorship. Who is the author? What are his or her other surveys or publications? What is his background and specialty? How many external references exist mentioning the author? Is it possible to find his bio? Does the author have any theoretical or ideological orientation? Is the author representing any institution in the text?

- Source. Does the page identify the editorial body? Does it have any tabs explaining its history, goals and location? What is the domain of the page address (.org, .com, .gov)? Is the page part of an institution? Does it have many ads? Does the information layout appear to be properly organized?

- Content. Does the text cite its sources? Are there cohesion and coherence in the arguments? Is the text clear and well written, according to the language standards? Is the subject matter of the text controversial? Does the text present different points of view on the subject in question? Does the text seem to be unbiased, or does it stand for a clear position in the argument? Is the language used by the text aggressive, 
or does it show some kind of prejudice? Is its language too informal? Can the conclusion of the text be inferred from its arguments? Does the title or call match your content?

- Context. Is there date and place of publication of the information? Is the text an author's personal opinion or is it presented as an account of events? Is it a real or fictional text? Why is this information being served at this time? What was the historical-social context at the time the text was produced? Do the text fonts appear to be reliable? Do the provided links work?

- Replication. Has the content of the information been served by more than a few sources? Who are the other sources that also disseminated the information?

The evaluation of information by technical criteria appears to result in a relatively mechanical and automated way of evaluating information. Despite being objective and very cooperative in filtering dis/misinformation at first, we believed that it needs an epistemological and philosophical complement that acts in a more committed way with the issue of critical thinking. This complement is important, so that the sense of evaluation is instilled in the individual in a more profound and permanent way. If the technical dimension responds to the 'how to', the semantic dimension is more related to 'why'.

\section{Semantic dimension}

The semantic dimension is based on the theories of Luciano Floridi about semantic information, and also approach his concept of information 'veridicality'. In addition, David Carraher's critical-sense comments complement this dimension.

\section{Semantic dimension, step 1: Types of information}

Firstly, we proposed to expand the Floridi definitions $(2011,2010)$ on data types (mentioned in Figure 1) to the information level. For this, an adaptation of the mentioned concepts is elaborated below, to define the first stage of the semantic dimension:

\section{Information reliability criteria (semantic dimension, 1)}

- Primary. Corresponds to direct data. It is the information created directly by the source reporting it. For example, an account of an event,

$$
\text { ectly by the source reporting it. For example, an account of an event, }
$$


coming from an eyewitness, is a primary data. The truthfulness of information from primary data is more difficult to verify, since it depends on the confidence of the presented report. In this sense, the technical dimensions of 'authority' and 'context' are essential for this parameter.

- Secondary. Corresponds to the data extracted by the absence of the primary data. For example, if a source does not mention the authorship of a text that it is divulging, it can be assumed that the text was drawn up by the source itself. Or, that the source did not take adequate care in the preparation of the text. In this case, the technical dimensions of 'content' and 'replication' are particularly important in this assessment.

- Meta. Corresponds to data about the nature of other data. It deals with how significant the technical aspects are for the information conveyed in the text (such as the date and time the information was published, or its Internet Protocol (IP) address). It refers to the technical dimensions of 'source' and 'authorship'.

- Operational. Data that refers to the operation of a system. For the semantic application of information, it would correspond to what, in the information source, would be working properly or not. The technical dimensions of 'source' and 'context' work on the issue involving the access and availability of the informational source to test its consistency and reliability.

- Derivative. Data that is extracted indirectly from other data. It is the category most related to critical reading in its essence, because it demands inferences, deductions and questions about what is in the 'between the lines' of the information made available. For example, information that bears a positive image of some institution may have been conveyed or created by a source maintained (or at least sensitized) by that institution. The technical dimensions of 'content' and 'context' relate to this category.

\section{Semantic dimension, step 2: Types of argumentation}

Another analysis, within the semantic dimension, is possible to be established using the approach of Carraher (1983) on the critical analysis. According to the author, confusion between ideas, opinions and facts is common. To clarify such confusion, he categorizes argumentative information into 'fact questions', 'value questions' and 'conceptual questions'. From the approach of Carraher (1983), another stage of the semantic dimension is presented: 
Information reliability criteria (semantic dimension, 2)

- Fact. Facts imply questions that present precise answers (usually only one), since they are not dealing neither with subjectivism nor interpretations of reality. As Carraher (1983: 119) puts it, "all assertions are human constructs, and therefore represent not the reality to which they relate, but there are certain assertions that are so evident and accepted, even among critical people, that are not problematic". As examples of what is a matter of fact, consider the following phrases: 'Florianópolis is the capital of Santa Catarina Estate'; 'The human body has a head'; 'The ice is solid'.

- Value. Questions involving values are those that are subject to opinions, personal tastes, aesthetic criticism and interpretations of events. They may be in the form of reasonable, clear, and intelligent statements, but ultimately they always refer to something that does not have unanimity of consensus, as it involves some kind of judgment. According to Carraher (1983: 121), "values involve taking positions on what is considered good or bad, desirable or reprehensible, worthy of praise or criticism, positive or negative". Examples of value issues include: 'Contemporary art is not art'; 'The Japanese football team is a bad one'; 'Whoever supports abortion is against life'.

- Concept. Conceptual issues deal with definitions and conceptions of a phenomenon. They therefore involve scientific and philosophical research within the current paradigm of knowledge. According to Carraher (1983: 123), "conceptual questions are those whose resolution depends on reflections on the nature of ideas and concepts, taking into account available evidence". They are questions that involve frequent reflection and questioning, and do not have definitive answers (mainly in the human sciences). As examples of concepts we have: 'The content of dreams is created by repressed desires'; 'There are different types of intelligence'; 'Information is data with meaning'.

Carraher (1983: 121) comments that the mixing of values with facts is mainly perceptive in discourses in which language hides the evaluative aspects within an statement such as, for example, in the sentence: "The adolescent has to go through many conflicts with the previous generation so that it can develop a sense of self-identity". As the author comments, although it sounds like a merely informative sentence, it suggests defending certain ideas or plans behind his message ('must pass' means a 'should pass'). This mix may have even higher levels of complexity, depending on the ability of the information producer to create his speech, and his interests towards his audience. It may 
be thought that such mixtures include, for example, the tactics of advertising and propaganda, marketing and image advisory, or even rhetorical, ideological and political discourses in general.

Carraher (1983: 122) also states that "however many people tries to justify ethical values and systems based on facts alone, the facts are not sufficient to justify values". Thus, facts do not prove that values are correct, and although some values may be derived from others, they cannot logically be derived from facts. An example that proves the error in the derivation of values/facts is in opposing arguments for the same statement, according to the schematization adapted from Carraher (1983) below:

Assuming (a) it is a fact:

(a) Households are earning less than the minimum wage currently.

Of this, someone argues that:

(b) So why am I going to pay more?

Thus, (b) it seems a natural derivation of (a).

However, another person may argue that:

(c) So, people have to recognize that this is exploitation and pay more!

Therefore, (b) and (c) show different conclusions for the same fact, which depend on different values of each arguer. Thus, facts do not justify values by themselves. Moreover, as Carraher (1983: 159) points out, "neither intelligence nor rationality constitute the basis of values. Modern history shows innumerable instances of how man uses his intelligence to accomplish destructive ends". However, since values influence ideas, it is permissible that they can also direct the focus of some conceptual issues, at a certain historical moment, even in science (Carraher (1983) mentions, for example, the creation of the atomic bomb). Total neutrality in any discourse thus seems impossible to attain, for a minimum of bias is always present, even if it is in the motivation behind a particular research. But, as Carraher (1983: 125) states, for example, "the fact that values contribute to the selection of topics investigated in science does not imply that scientific analyzis are necessarily biased and worthless".

The last stage of the semantic dimension retakes the work of Luciano Floridi to analyze the content of an information and evaluate its "informativeness".

\section{Semantic dimension, step 3: Informativeness}

When Floridi $(2010,2011)$ defines the concept of information historically present in the literature, he criticizes the lack of alhetical values in its definition. 
This is how he develops the 'strongly semantic information theory' as a result of quantitative theories of information that are based on probabilistic distributions and which generate the so-called 'Bar-Hillel-Carnap Paradox'.

In short, the Bar-Hillel-Carnap Paradox arises when, in analyzing information from the point of view of quantitative information theories, the result points out that contradictions are the propositions that most present a level of maximum 'information'. Floridi (2010) argues, then, that this paradox can be avoided precisely by adopting its concept of 'semantic information', which encompasses correspondence with truth as a requirement for something to be considered information.

In the strongly semantic information theory, Floridi (2011) proposes that a quantitative analysis of information can be done in terms of informativeness, and involving levels of 'vacuity' and 'inaccuracy'.

Informativeness corresponds to a function that calculates the level (positive or negative) of 'semantic distance' or 'deviation' from a piece of semantic information (which can, therefore, be evaluated as true or false) in relation to a fixed point of origin, within a defined situation to which this piece of information supposedly refers. Thus, informativeness can be calculated by taking into account the alethic value of the piece of information, and the level of discrepancy between this piece of information and a particular state of the environment, which also determines its accuracy. Floridi (2011) clarifies with the following example:

a) Fact - There are nine people in the library;

b) Affirmation 1 - There are ten people in the library;

c) Affirmation 2 - There are fifty people in the library;

d) Affirmation 3 - There is someone in the library;

e) Affirmation 4 - There are nine or ten people in the library.

Analyzing the items, it is verified that the affirmations b) and c) are false. However, c) has a level of discrepancy greater than b) in relation to fact a). Assertions $\mathrm{d}$ ) and e) are true, but e) is more precise (and therefore less vague) than d).

On this, the notion of vacuity arises as the distance from the piece of true information to the point of origin. The more vacuity, the less specific and precise the information, and the more generalized it is. For Floridi (2011), the positive end of a discrepancy results in a tautology. The negative extreme results in a contradiction, which also qualifies as the maximum level of semantic imprecision. 
As an illustration, Figure 2 graphically represents the concepts related to the level of information:

MAXIMUM INFORMATIVENESS

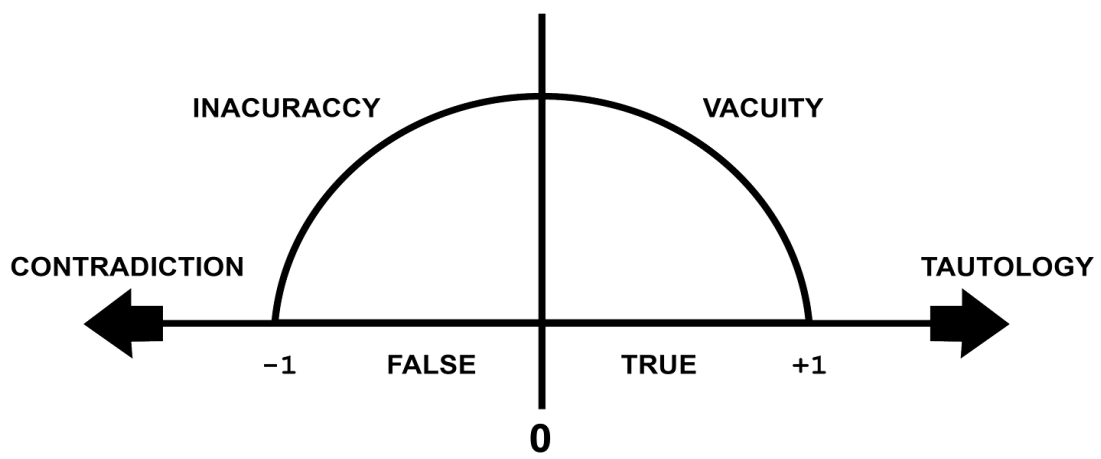

Based on the assumptions above, the concept of informativeness, which represents the third part of the semantic dimension, is presented as a part of the criteria of information reliability, in this research:

Informativeness corresponds to the level of relevance and accuracy of the information. Information with high informativeness relates to semantic information rich in meaning, but at the same time, it has the lowest possible degree of vacuity and imprecision. In practice, verification of informativeness can be done by critically analyzing the information presented, either through the user's direct reading and interpretation of the text, or in comparison with information presented by other sources. Such analysis involves recognizing whether information is being vague and general in its claims, and whether it is presenting contradictions and inaccuracies in relation to the subject it is reporting.

As a closure, Table 1 is presented with the schematization of the three stages of the semantic dimension, grouped together with the criteria of the technical dimension.

\begin{tabular}{|c|c|c|c|}
\hline \multicolumn{3}{|c|}{ Information reliability criteria } \\
\hline Technical dimension & \multicolumn{3}{|c|}{ Semantic dimension } \\
\hline Autorship & $\begin{array}{c}\text { Types } \\
\text { of information }\end{array}$ & $\begin{array}{c}\text { Types of } \\
\text { argumentation }\end{array}$ & Informativeness \\
\hline Source & Primary & Fact & Imprecision \\
\hline Content & Secundary & Value & Vacuity \\
\hline
\end{tabular}




\begin{tabular}{|c|c|c|c|}
\hline Context & Meta & Concept & Contradiction \\
\hline Replication & Operational & & Tautology \\
\hline & Derivative & & \\
\hline
\end{tabular}

Table 1. Information reliability criteria Source: prepared by the authors (2019)

Thus, the semantic dimension discussion concludes its purpose in participating of the information reliability criteria.

\section{CONCLUSION: KRITERION AND RELIABILITY, THE ENDLESS SEARCH}

The search for information reliability criteria proposes an introductory and easily disseminated way to fight against dis/misinformation in the digital environment. By inciting the individual to perform critical reading, such action is but one possibility in the process of necessary education to enable people to interact with this environment.

Criteria limit, but should not be limited: new ways of analyzing information may cause the forthcoming of many other criteria and may create other dimensions of analysis, or improve and correct those developed by this research. As a natural consequence of the critical thinking exercise, such analysis encompasses the creation of qualitative demands about information, as a reflexive action to deal with the problems of a society in an increasing immersion into the misinformation pool.

We believed that the search for criteria of reliability will always undergo processes of 'virtualization' and 'actualization' (in Lévy's terms), in constant readjustment to the dynamics of relations, creations and transformations of the society and the individual, in his endless attempt to 'semanticise' and understand the world. This search must also be objective in its purpose without, however, failing to recognize the subjectivity that characterizes human actions, which must be categorized whenever a clarity of what path to take for actually reach knowledge is needed.

The construction of criteria to evaluate information, far from being an accurate and infallible formula, is only an initial orientation in a much larger process that involves the construction of knowledge through the way of critical reading and critical thinking. The reading, however, is related to the first side of the problem in this crisis scenario. Its action has to do with the reception of information. However, in the context of cyberculture, every recipient is also a probable source of information. 
Therefore, the other side of the problem is related to the dissemination of information by the individual, in his social networks and social applications. Although it is expected that critical reading and analysis will cause the individual not only to avoid misinformation for himself, but also for everyone, it seems that a complement is necessary to critical thinking. This complement has to do with the use of ethics as a guide to the epistemological basis regarding the sharing of content on the web. Because, under such a scenario, no individual can be exempt from responsibility in the dissemination of information. In this sense, critical thinking also acts as a motor for the possible realization of 'collective intelligence': the learning of individual abilities, specially literacies, must resonate in the collective dimension of cyberspace, not as a way of creating isolated units of knowledge, but to bring to the understanding that a healthy and rich informational environment is only possible by thinking of others.

Moreover, although the current paradigm of knowledge seems to distance itself from the positivist philosophy of science and approach a hermeneutic line, it is considered necessary to retake objectivity in some concepts that guide communication, including the concept of truth. When adopting an orientation that one could call 'positive', to base epistemologically the concepts of this research, we are not intended, however, to disregard the dialectics and multiplicities that characterize the social environment and base the most recent theoretical representations of knowledge.

\section{REFERENCES}

Bennett, W. Lance and Steven Livingston. 2018. "The disinformation order: disruptive communication and the decline of democratic institutions". European Journal of Communication 33(2): 122-139.

https://journals.sagepub.com.ez46.periodicos.capes.gov.br/doi pdf/10.1177/0267323118760317

Carraher, David William. 1983. Senso crítico: do dia-a-dia às ciências bumanas. São Paulo: Livraria Pioneira.

Cleveland State University. The Writing Center. 2017. "Critical reading: what is critical reading, and why do I need to do it?".

http://www.csuohio.edu/writing-center/critical-reading-what-critical-readingand-why-do-i-need-do-it

Cambridge English Dictionary. 2019a, s.v. "criterion". https://dictionary.cambridge.org/pt/dicionario/ingles/criterion

Cambridge English Dictionary. 2019b, s.v. "criticism". https://dictionary.cambridge.org/pt/dicionario/ingles/criticism

Dawkins, Richard. 2007. O gene egoísta, 2th ed. São Paulo: Companhia das Letras.

Dewey, John. 1997. How we think. New York: Dover. 
Dudziak, Elisabeth Adriana, Sueli Mara Soares Pinto Ferreira and Adriana Cybele Ferrari. 2017. "Competência Informacional e Midiática: uma revisão dos principais marcos políticos expressos por declarações e documentos”. Revista Brasileira de Biblioteconomia e Documentação 13 (1): 213-253.

https://rbbd.febab.org.br/rbbd/article/view/675

Fallis, Don T. 2015. "What is disinformation?" Library Trends 63 (3): 401-426. https://muse.jhu.edu/article/579342/pdf

Floridi, Luciano. 2010. Information: a very short introduction. Oxford: Oxford University Press.

Floridi, Luciano. 2011. The philosophy of information. Oxford: Oxford University Press. Freire, Paulo. 1988. Educação e mudança, 4th ed. São Paulo: Paz e Terra.

Goldman, Alvin. 1993. "Reliabilism". In: A companion to epistemology, edited by Jonathan Dancy and Ernest Sosa, 312-314. Oxford: Blackwell Scientific Publications.

Hjørland, Birger. 2012. "Methods for evaluating information sources: an annotated catalogue". Journal of Information Science 38 (3): 258-268. http://journals.sagepub.com/doi/pdf/10.1177/0165551512439178

Leite, Leonardo Ripoll Tavares. 2018. "Confiabilidade informacional : a filosofia da informação e o desenvolvimento da leitura crítica no ambiente virtual”. Dissertação de mestrado, Universidade do Estado de Santa Catarina, Centro de Ciências Humanas e da Educação, Programa de Pós-Graduação em Gestão da Informação. http://www.bu.ufsc.br/teses/UDESC0036-D.pdf

Lévy, Pierre. 2010. Cibercultura. São Paulo: Ed. 34.

Marcos Recio, Juan Carlos, Juan Miguel Sánchez Vigil and María Olivera Zaldua. 2017. "La enorme mentira y la gran verdad de la información en tiempos de la postverdad". Scire 23 (2): 13-23.

https://www.ibersid.eu/ojs/index.php/scire/article/view/4446/3896

Moretzsohn, Sylvia Debossan. 2017. “Uma legião de imbecis': hiperinformação, alienação e o fetichismo da tecnologia libertarian”. Liinc em Revista 13 (2): 294-306. http://revista.ibict.br/liinc/article/view/4088

Olmo y Romero, Julia Alicia. 2019. "Desinformación: concepto y perspectivas”. CIBER Elcano (43): 1-8.

http://www.realinstitutoelcano.org/wps/portal/rielcano_es/contenido?WCM_ GLOBAL_CONTEXT=/elcano/elcano_es/zonas_es/ari41-2019-olmoromero-desinformacion-concepto-y-perspectivas .

Oxford University Press. 2019. Word of the year 2016 is... https://en.oxforddictionaries.com/word-of-the-year/word-of-the-year-2016

Peirce, Charles Sanders. 1980. "The fixation of belief”. In: Peirce: Selected writings, edited by Philip Weiner, 91-112. New York: Dover.

Posetti, Julie. 2018. "News industry transformation: digital technology, social platforms and the spread of misinformation and disinformation". In: Journalism, 'fake news' E disinformation: handbook for journalism education and training, edited by Cherilyn Ireton and Julie Posetti, 55-69. Paris: UNESCO.

https://en.unesco.org/sites/default/files/journalism_fake_news_disinformation_print_friendly_0.pdf

Silverman, Craig. 2015. Lies, damn lies and viral content. New York: Columbia Journalism School. https://academiccommons.columbia.edu/doi/10.7916/D8KH10RQ/download 
Tomaél, Maria Inês, Adriana Rosecler Alcará and Terezinha Elisabeth da Silva. 2008. "Fontes de informação na internet: critérios de qualidade". In: Fontes de informação na internet, edited by Maria Inês Tomaél, 3-28. Londrina: Eduel.

University of Leicester. Student Learning Development. 2009. What is critical reading. https://www2.le.ac.uk/offices/ld/resources/study-guides-pdfs/writing-skills-pdfs/ critical-reading-v1\%200.pdf

Vicario, Michela Del, Alessandro Bessi, Fabiana Zollo, Fabio Petroni, Antonio Scala, Guido Caldarelli, H. Eugene Stanley and Walter Quattrociocchi. 2016. "The spreading of misinformation online". Proceedings of National Academy of Sciences of the United States 113 (3): 554-559.

https://www.pnas.org.ez46.periodicos.capes.gov.br/content/113/3/554

Vosoughi, Soroush, Deb Roy and Sinan Aral. 2018. "The spread of true and false news online". Science 359 (6380): 1146-1151.

http://science.sciencemag.org/content/359/6380/1146.full

Para citar este texto:

Ripoll, Leonardo and José Claudio Matos. 2020. "Information reliability: criteria to identify misinformation in the digital environment". Investigación Bibliotecológica: archivonomía, bibliotecología e información 34 (84): 79-101.

http://dx.doi.org/10.22201/iibi.24488321xe.2020.84.58115 